\title{
The effects of xanthan gum on equine sperm quality during cooling storage
}

[Efeitos de xantam gum em qualidade de esperma equino durante armazenamento resfriado]

\author{
S.M.M. Gheller ${ }^{1}$, C.D. Corcini ${ }^{2 *}$, F.C.C. Santos ${ }^{1,2}$, G.C. Tavares ${ }^{2}$, V.G.G. Costa ${ }^{2}$, \\ B.R. Curcio $^{2}$, C.E.W. Nogueira ${ }^{2}$, A.S. Varela Junior ${ }^{2,3}$ \\ ${ }^{1}$ Aluno de pós-graduação - Universidade Federal de Pelotas - Pelotas, RS \\ ${ }^{2}$ Universidade Federal de Pelotas - Pelotas, RS \\ ${ }^{3}$ Universidade Federal de Rio Grande - Rio Grande, RS
}

\begin{abstract}
This study was designed to evaluate the possible benefits of adding xanthan gum to a standard extender for equine through in vitro analyzes of sperm quality. Semen was collected four times from five different stallions ( $\mathrm{n}=20$ samples) and subjected to cooled storage under different conditions: control (only standard extender) and three different concentrations of xanthan gum $(0.01 \%, 0.12 \%$, and $0.25 \%)$ supplemented to the extenders. Sperm parameters, such as motility, mitochondrial functionality, and membrane, acrosome, and DNA integrity were measured after $0 \mathrm{~h}, 24 \mathrm{~h}, 48 \mathrm{~h}$, and $72 \mathrm{~h}$ of sperm storage at $5^{\circ} \mathrm{C}$. Our observations indicated that sperm motility declined with longer cooling period with the $0.25 \%$ xanthan gum supplementation group compared with the control group. Other parameters, such as mitochondrial functionality and membrane and acrosome integrity also declined for all treatments during storage; however, no differences were observed between xanthan gum and control groups. DNA integrity did not significantly change during the storage. In conclusion, the addition of xanthan gum to equine semen extender is not harmful to the sperm structure, despite reducing the sperm motility.
\end{abstract}

Keywords: cooled, stallion, semen, spermatozoa, storage

\section{RESUMO}

Esse estudo foi desenvolvido para avaliar os possíveis benefícios de acrescentar xanthan gum a um extensor padrão através de analises in vitro de qualidade de esperma. Semen foi coletado quatro vezes de cinco garanhões diferentes $(n=20$ amostras) e submetido a armazenamen to resfriado em diferentes condições: controle (apenas extensor padrão) e três diferentes concentrações de xanthan gum $(0,01 \%$, $0,12 \%$ e 0,25\%) suplementado aos extensores. Parâmetros dos espermatozoides, como mobilidade, funcionamento mitocondrial e integridade de membranas, acrossomos e DNA forma medidos após Oh, $24 \mathrm{~h}, 48 \mathrm{~h}$ e $72 \mathrm{~h}$ de armazenamento a 5oC. Nossas observações indicaram que motilidade reduziu com armazenamento resfriado prolongado no grupo de 0,25\% de suplementação de xanthan gum comparado ao grupo controle. Outros parâmetros, como funcionalidade mitocondrial e integridade de membrana e acrossomos também reduziu em todos os tratamentos durante o armazenamento, no entanto não foram detectadas diferenças significativas entre grupos tratados e grupo controle. Integridade de DNA não mudou significativamente durante armazenamento. Em conclusão, a adição de xanthan gum a extensor de sêmen equino não é danosa à estrutura do espermatozoide apesar de reduzir motilidade.

Palavras-chave: resfriamento, garanhão, sêmen, espermatozoide, armazenamento

\section{INTRODUCTION}

Artificial insemination in horses is widely practiced throughout the world by processing equine semen for cooled transport. In the cooled transport conditions, inseminations can be carried out for the equine semen for up to $48 \mathrm{~h}$ when stored at $5^{\circ} \mathrm{C}$ (Scott Weese et al., 2011). However, this reduction in temperature causes structural changes in the spermatozoa, which can compromise their functional integrity, either by thermal shock or by the production of free

Recebido em 26 de junho de 2017

Aceito em 17 de maio de 2018

* Autor para correspondência (corresponding author)

E-mail: corcinicd@gmail.com 
radicals from spermatic catabolism (Watson, 2000). The thicker diluents maintain the homogeneity of the sperm cells in the diluent medium, and metabolically less active, being able to resurrect in a smaller formation of ROS (Lopez-Gatius et al., 2005; Nagy et al., 2002). Xanthan gum has already been demonstrated in other studies with sperm cells (Gastal et al., 2017) that may exert antioxidant effect. And second, due to the antioxidant activity of xanthan oligosaccharides may be due to the presence of pyruvate acid residues and to their capacity of reducing sugar content (Xiong et al., 2013).

Extenders have been used for equine semen refrigeration, and they usually contain milk. However, there is a considerable variation in fertilization rates using refrigerated semen samples transported in milk-based extenders (Scott et al., 2011). Studies to improve the conservation of refrigerated semen have focused on modifying extenders using a combination of various components, such as sugars, electrolytes, buffers, egg yolks, milk, antioxidants, and adjuvants (Scott et al., 2011). The addition of such components was meant to help maintain membrane integrity, prevent oxidative stress, and preserve sperm motility (Samper et al., 2002).

In addition to the above-mentioned factors, sperm cell survival and functional integrity are also dependent on the spatial arrangement of the refrigerated samples. This is achieved through homogenization that helps avoid cell sedimentation (Holt, 2000). The beneficial effects of addition of gelatin to tris / yolk-based cooling diluents and milk powder on refrigeration demonstrated beneficial effects in studies with rabbits ( Nagy et al., 2002; LopezGatius et al., 2005), sheep (Yaniz et al., 2005), and goats (Salvador et al., 2006).

Xanthan gum, a naturally occurring, high molecular weight biopolymer produced by Xanthomonas campestris, increases the viscosity (in the presence of salts) and stability during storage over a wide temperature range (4 and $\left.93^{\circ} \mathrm{C}\right)$. In addition, xanthan gum has the potential to reduce cellular damage during the cooling process by acting as an external cryoprotectant by increasing the viscosity of the extender medium and by having antioxidant effects. There is no study on the effect of diluents supplemented with xanthan gum to enhance the storage properties of stallion semen. Thus, the objective of this work was to evaluate the effects of adding xanthan gum to the equine cooling extender, and how that affects sperm parameters in vitro during storage at $5^{\circ} \mathrm{C}$ for $72 \mathrm{~h}$.

\section{MATERIALS AND METHODS}

We performed four semen collections from five different fertile stallions $(n=20$ samples $)$ belonging to Crioulo and Quarter horse, age 4-6 years, during the reproductive season. Semen ejaculates were collected utilizing a teaser mare and artificial vagina (Hannover, Minitüb ${ }^{\mathrm{TM}}$ ), and processed at the Núcleo de Ensino e Pesquisa em Reprodução Animal- REPROPEL of Federal University of Pelotas - UFPel. The experiments were carried out after obtaining due approval from the "Committee of Ethics in Animal Experimentation," Federal University of Pelotas (UFPel), S.No. 1946.

The base diluent used was Kenney extender (1975), having $\mathrm{pH}$ 6.9, and osmolality of $380 \mathrm{mOsm} / \mathrm{Kg}$. The diluent was prepared the day before semen collection, and stored at $-5^{\circ} \mathrm{C}$. It was reheated in a water bath to achieve the temperature of $33^{\circ} \mathrm{C}$ immediately before use. The semen samples were diluted in the base extender $(1: 1, \mathrm{v} / \mathrm{v})$ at the time of collection and immediately evaluated for motility and sperm vigor. The ejaculates had sperm motility $\geq 70 \%$ and sperm disease $<30 \%$. The final dilution was performed after determining the sperm concentration of the samples diluted in formaldehyde (Bearden e Fuquay, 1997) B). The final dilution used was $50 \times 10^{6}$ viable spermatozoa $/ \mathrm{mL}$ in the following treatments at room temperature: Kenney only (control group) and Kenney containing $0.01 \%, 0.12 \%$, and $0.25 \%$ xanthan gum (treatment groups). The cooling curve was performed using a conditioning box (Koolmate, Minitube, Ge) with a cooling rate of $0.3-0.5^{\circ} \mathrm{C} / \mathrm{min}$ until a temperature of $5^{\circ} \mathrm{C}$ was achieved followed by storage for a period of $72 \mathrm{~h}$.

Prior to the analysis, all conditioned samples that were cooled for $0 \mathrm{~h}, 24 \mathrm{~h}, 48 \mathrm{~h}$ and $72 \mathrm{~h}$, were heated in a water bath $\left(5 \mathrm{~min} / 37^{\circ} \mathrm{C}\right)$. Subsequently, 200 cells were counted per sample, except in the case of sperm motility experiments. 
For sperm motility, $10 \mu \mathrm{L}$ of sperm, maintained at $37^{\circ} \mathrm{C}$ on a heated plate, was examined using phase-contrast optical microscopy at 200x magnification (Bearden e Fuquay, 1997).

The functionality was evaluated as described by (Garner et al., 1997). Briefly, 20 $\mu \mathrm{L}$ of the semen was added to $13 \mathrm{mM}$ Rhodamine 123 (Rh123, R8004), followed by Propidium Iodide (PI, $\mathrm{P} 4170$ ). The samples were incubated for $5 \mathrm{~min}$ in the dark in $24^{\circ} \mathrm{C}$ and immediately examined microscopically. The cells with intense green fluorescence in the intermediate part were considered functionally active, whereas the cells with less intense or without any green fluorescence in the intermediate part were considered functionally inactive.

The membrane integrity was measured according to the protocol described by (Harrison and Vickers, 1990). Briefly, 20 $\mu \mathrm{L}$ of semen was added to carboxyfluorescein diacetate (CFDA, C4916), followed by Propidium Iodide (PI, $\mathrm{P} 4170)$ in formaldehyde and sodium citrate, and incubated for $5 \mathrm{~min}$ in the dark in $24^{\circ} \mathrm{C}$. Cells showing green fluorescence were considered intact, while cells with red or green/red fluorescence were considered damaged.

The acrosome integrity (Kawamoto et al., 1999) was evaluated on semen smears prepared using $20 \mu \mathrm{L}$ of semen. Propidium iodide (PI, P4170) $(20 \mu \mathrm{L})$ was added to this smear, the slides were dried, immersed in absolute ethyl alcohol (459844-1L) for 5min, washed in PBS, followed by the addition of $20 \mu \mathrm{L}$ of Arachis hypogaeaFITC Lectin Conjugate $(20 \mathrm{mg} / \mathrm{mL})$. The slides were subsequently washed in deionized water and drained in a dark room in $24^{\circ} \mathrm{C}$. The cells with intact acrosome emitted green fluorescence, whereas those with damaged acrosome appeared rough with vacuoles, and did not emit green fluorescence.
The DNA integrity was evaluated using the Acridine Orange dye (A6014), as per the protocol of (Evenson et al., 1999). Briefly, 10 $\mu \mathrm{L}$ of TNE $(0.01 \mathrm{M}$ Tris- $\mathrm{HCl}, 0.15 \mathrm{M} \mathrm{NaCl}, 0.001 \mathrm{M}$ EDTA, pH 7.2) was added to $20 \mu \mathrm{L}$ of semen. After $30 \mathrm{~s}, 100 \mu \mathrm{L}$ of Triton $(1 \mathrm{x})$ was added, and after another $30 \mathrm{~s}, 50 \mu \mathrm{L}$ of Acridine Orange $(2 \mathrm{mg} / \mathrm{mL}$ in deionized water) was added, followed by incubation for $5 \mathrm{~min}$ in $24^{\circ} \mathrm{C}$. The cells with normal (double-stranded) DNA had green fluorescence, whereas those with red fluorescence were considered to have denatured (single-stranded) DNA.

The membrane integrity, acrosome, DNA and mitochondrial functional integrity analyses were performed using a WU filter, with excitations of $450-490 \mathrm{~nm}$ and emission of $516-617 \mathrm{~nm}$, by employing an epifluorescence microscope (Olympus BX 51, São Paulo, SP).

Since the Shapiro-Wilk test indicated a lack of normality, all responses were subjected to arcsine transformation. Subsequently, transformed data were compared among treatments using the analysis of variance (ANOVA) with repeated measures, with the effect of individual animals nested within the effect of sperm collections. The comparison of means was done using Tukey's test. To allow for a straightforward interpretation, the results were reported in their original scale. All analyses were carried out using Statistix ${ }^{\text {TM }}$ (2013).

\section{RESULTS}

When sperm motility was evaluated in the presence and absence of xanthan gum, a significant difference was observed between the control (no xanthan gum) and xanthan gum treatment $(0.25 \%)$. At the $24 \mathrm{~h}$ cooling period, we observed that xanthan gum, at $0.25 \%$, significantly reduced sperm motility, when compared to control values (Table 1).

Table 1. Percentage sperm motility (mean \pm standard error of the mean) of stallion semen subjected to cooled storage at $5^{\circ} \mathrm{C}$ for $72 \mathrm{~h}$ and treatment with xanthan gum

\begin{tabular}{ccccc} 
Hour & $0 \%$ & $0.01 \%$ & $0.12 \%$ & $0.25 \%$ \\
\hline 0 & $85.0 \pm 1.0^{\mathrm{A}, \mathrm{a}}$ & $85.0 \pm 1.0^{\mathrm{A}, \mathrm{a}}$ & $85.0 \pm 1.0^{\mathrm{A}, \mathrm{a}}$ & $85.0 \pm 1.0^{\mathrm{A}, \mathrm{a}}$ \\
24 & $60.5 \pm 1.6^{\mathrm{AB}, \mathrm{b}}$ & $63.6 \pm 2.5^{\mathrm{A}, \mathrm{a}}$ & $51.5 \pm 2.0^{\mathrm{BC}, \mathrm{b}}$ & $44.7 \pm 2.6^{\mathrm{C}, \mathrm{b}}$ \\
48 & $43.6 \pm 2.6^{\mathrm{A}, \mathrm{bc}}$ & $41.0 \pm 2.1^{\mathrm{A}, \mathrm{b}}$ & $33.6 \pm 2.4^{\mathrm{AB}, \mathrm{bc}}$ & $25.2 \pm 2.2^{\mathrm{B}, \mathrm{bc}}$ \\
72 & $26.8 \pm 3.1^{\mathrm{A}, \mathrm{c}}$ & $23.1 \pm 2.9^{\mathrm{AB}, \mathrm{b}}$ & $18.2 \pm 2.5^{\mathrm{AB}, \mathrm{c}}$ & $23.3 \pm 2.4^{\mathrm{B}, \mathrm{c}}$ \\
\hline
\end{tabular}

${ }^{A, B}$ Different capital letters indicate the difference in rows $(\mathrm{P}<0.05)$.

${ }^{a, b, c}$ Different lowercase letters indicate the difference in columns $(\mathrm{P}<0.05)$. 
The mitochondrial functionality measurements (Table 2) revealed no overall difference between control and xanthan gum treatments. However, when the cooling period was considered, the xanthan gum treatments lowered mitochondrial functionality, both after $48 \mathrm{~h}$ and $72 \mathrm{~h}$ of cooling.
This was not seen when xanthan gum concentration was $0.12 \%$ or $0.25 \%$.

Similarly, xanthan gum decreased the percentage of membrane integrity (Table 3). Xanthan gum treatments, as well the control group, reduced membrane integrity as early as $24 \mathrm{~h}$ of cooling.

Table 2. Percentage mitochondrial functionality (mean \pm standard error of the mean) of stallion semen subjected to cooled storage at $5^{\circ} \mathrm{C}$ for $72 \mathrm{~h}$ and treatment with xanthan gum

\begin{tabular}{ccccc}
\hline Hour & $0 \%$ & $0.01 \%$ & $0.12 \%$ & $0.25 \%$ \\
\hline 0 & $76.6 \pm 1.5^{\mathrm{A}, \mathrm{a}}$ & $76.6 \pm 1.5^{\mathrm{A}, \mathrm{a}}$ & $76.6 \pm 1.5^{\mathrm{A}, \mathrm{a}}$ & $76.6 \pm 1.5^{\mathrm{A}, \mathrm{a}}$ \\
24 & $74.6 \pm 2.5^{\mathrm{A}, \mathrm{a}}$ & $70.9 \pm 3.9^{\mathrm{A}, \mathrm{ab}}$ & $69.7 \pm 3.2^{\mathrm{A}, \mathrm{ab}}$ & $70.3 \pm 3.2^{\mathrm{A}, \mathrm{ab}}$ \\
48 & $63.0 \pm 3.6^{\mathrm{A}, \mathrm{ab}}$ & $63.1 \pm 2.4^{\mathrm{A}, \mathrm{bc}}$ & $64.7 \pm 3.4^{\mathrm{A}, \mathrm{ab}}$ & $60.0 \pm 2.5^{\mathrm{A}, \mathrm{bc}}$ \\
72 & $50.4 \pm 3.1^{\mathrm{A}, \mathrm{b}}$ & $50.8 \pm 4.1^{\mathrm{A}, \mathrm{c}}$ & $51.8 \pm 4.9^{\mathrm{A}, \mathrm{b}}$ & $43.6 \pm 5^{\mathrm{A}, \mathrm{c}}$ \\
\hline
\end{tabular}

${ }_{\mathrm{A}, \mathrm{B}}$ Different capital letters indicate the difference in rows $(\mathrm{P}<0.05)$.

a,b,c Different lowercase letters indicate the difference in columns $(\mathrm{P}<0.05)$.

Table 3. Percentage plasma membrane integrity (mean \pm standard error of the mean) of stallion semen subjected to cooled storage at $5^{\circ} \mathrm{C}$ for $72 \mathrm{~h}$ and treatment with xanthan gum

\begin{tabular}{ccccc}
\hline Hour & $0 \%$ & $0.01 \%$ & $0.12 \%$ & $0.25 \%$ \\
\hline 0 & $81.8 \pm 1.3^{\mathrm{A}, \mathrm{a}}$ & $81.8 \pm 1.3^{\mathrm{A}, \mathrm{a}}$ & $81.8 \pm 1.3^{\mathrm{A}, \mathrm{a}}$ & $81.8 \pm 1.3^{\mathrm{A}, \mathrm{a}}$ \\
24 & $61.2 \pm 1.6^{\mathrm{A}, \mathrm{b}}$ & $62.3 \pm 3.2^{\mathrm{A}, \mathrm{b}}$ & $61.7 \pm 3.4^{\mathrm{A}, \mathrm{b}}$ & $62.4 \pm 2.8^{\mathrm{A}, \mathrm{b}}$ \\
48 & $43.3 \pm 4.1^{\mathrm{A}, \mathrm{bc}}$ & $46.3 \pm 3.7^{\mathrm{A}, \mathrm{bc}}$ & $52.9 \pm 3.3^{\mathrm{A}, \mathrm{bc}}$ & $51.1 \pm 2.9^{\mathrm{A}, \mathrm{bc}}$ \\
72 & $39.4 \pm 3.3^{\mathrm{A}, \mathrm{c}}$ & $40.3 \pm 3.1^{\mathrm{A}, \mathrm{c}}$ & $43.0 \pm 3.6^{\mathrm{A}, \mathrm{c}}$ & $39.6 \pm 3^{\mathrm{A}, \mathrm{c}}$ \\
\hline
\end{tabular}

${ }^{\mathrm{A}, \mathrm{B}}$ Different capital letters indicate the difference in rows $(\mathrm{P}<0.05)$.

${ }^{a, b, c}$ Different lowercase letters indicate the difference in columns $(\mathrm{P}<0.05)$.

The acrosome integrity measurements also indicated a significant decline, starting from $24 \mathrm{~h}$ of cooling (Table 4), both in the control and $0.25 \%$ xanthan gum groups.
The DNA integrity was unchanged at different cooling periods, and the statistical analysis revealed no difference between the different groups (Table 5).

Table 4. Percentage acrosome integrity (mean \pm standard error of the mean) of stallion semen subjected to cooled storage at $5^{\circ} \mathrm{C}$ for $72 \mathrm{~h}$ and treatment with xanthan gum

\begin{tabular}{ccccc} 
Hour & $0 \%$ & $0.01 \%$ & $0.12 \%$ & $0.25 \%$ \\
\hline 0 & $79.1 \pm 1.6^{\mathrm{A}, \mathrm{a}}$ & $79.1 \pm 1.6^{\mathrm{A}, \mathrm{a}}$ & $79.1 \pm 1.6^{\mathrm{A}, \mathrm{a}}$ & $79.1 \pm 1.6^{\mathrm{A}, \mathrm{a}}$ \\
24 & $61 \pm 2.9^{\mathrm{A}, \mathrm{b}}$ & $63.6 \pm 3.2^{\mathrm{A}, \mathrm{ab}}$ & $63.6 \pm 3^{\mathrm{A}, \mathrm{ab}}$ & $62.5 \pm 3.6^{\mathrm{A}, \mathrm{b}}$ \\
48 & $55.5 \pm 2.2^{\mathrm{A}, \mathrm{b}}$ & $54.1 \pm 3.2^{\mathrm{A}, \mathrm{b}}$ & $48.8 \pm 3.8^{\mathrm{A}, \mathrm{b}}$ & $58.5 \pm 3.8^{\mathrm{A}, \mathrm{b}}$ \\
72 & $52.9 \pm 4.1^{\mathrm{A}, \mathrm{b}}$ & $53.5 \pm 2.9^{\mathrm{A}, \mathrm{b}}$ & $48.7 \pm 3.5^{\mathrm{A}, \mathrm{b}}$ & $48.3 \pm 3.4^{\mathrm{A}, \mathrm{b}}$ \\
\hline
\end{tabular}

${ }_{\mathrm{A}, \mathrm{B}}$ Different capital letters indicate the difference in rows $(\mathrm{P}<0.05)$.

a,b,c Different lowercase letters indicate the difference in columns $(\mathrm{P}<0.05)$.

Table 5. Percentage DNA integrity (mean \pm standard error of the mean) of stallion semen subjected to cooled storage at $5^{\circ} \mathrm{C}$ for $72 \mathrm{~h}$ and treatment with xanthan gum

\begin{tabular}{ccccc}
\hline Hour & $0 \%$ & $0.01 \%$ & $0.12 \%$ & $0.25 \%$ \\
\hline 0 & $99.8 \pm 0.5^{\mathrm{A}, \mathrm{a}}$ & $99.8 \pm 0.5^{\mathrm{A}, \mathrm{a}}$ & $99.8 \pm 0.5^{\mathrm{A}, \mathrm{a}}$ & $99.8 \pm 0.5^{\mathrm{A}, \mathrm{a}}$ \\
24 & $99.8 \pm 0.5^{\mathrm{A}, \mathrm{a}}$ & $99.6 \pm 0.5^{\mathrm{A}, \mathrm{a}}$ & $98 \pm 1.3^{\mathrm{A}, \mathrm{a}}$ & $98.8 \pm 1.2^{\mathrm{A}, \mathrm{a}}$ \\
48 & $99.4 \pm 0.5^{\mathrm{A}, \mathrm{a}}$ & $98.4 \pm 0.6^{\mathrm{A}, \mathrm{a}}$ & $97.7 \pm 1.6^{\mathrm{A}, \mathrm{a}}$ & $99.6 \pm 0.1^{\mathrm{A}, \mathrm{a}}$ \\
72 & $99.3 \pm 0.5^{\mathrm{A,a}}$ & $99.4 \pm 0.5^{\mathrm{A,a}}$ & $97.7 \pm 2.1^{\mathrm{A}, \mathrm{a}}$ & $99.6 \pm 0.5^{\mathrm{A}, \mathrm{a}}$ \\
\hline
\end{tabular}

${ }^{\mathrm{A}, \mathrm{B}}$ Different capital letters indicate the difference in rows $(\mathrm{P}<0.05)$.

a,b,c Different lowercase letters indicate the difference in columns $(\mathrm{P}<0.05)$. 


\section{DISCUSSION}

This is the first study that tested xanthan gum as an additive to the standard diluent used for equine semen refrigeration. Xanthan gum is known to increase the viscosity of the medium, in part, owing to its thickening property in aqueous solution. An increased viscosity due to xanthan gum has been attributed to intermolecular or entanglement interactions, which increase the effective macromolecule size and molecular weight (Garcia-Ochoa et al., 2000).

Its higher viscosity prevented cell sedimentation by keeping them dispersed in the diluent medium, being already described in other species as a favorable condition to the cells with the usage of other extenders with higher viscosity, since it eliminates the need for sample homogenization and by promoting a greater contact of the cells with the diluent medium.

We used for this work a slow cooling curve till it reached $5^{\circ} \mathrm{C}$ for a $72 \mathrm{~h}$ storage, non-higher than $0,05^{\circ} \mathrm{C} / \mathrm{min}$, between 19 and $8^{\circ} \mathrm{C}$, since in this temperature range the membrane lipids are crossing the transition phase, from a fluid to a gel state, increasing the occurrence of lesions at the level of cell membranes (Squires et al., 1999), thereby minimizing the existence of damages to the plasma membrane by heat shock. This may be testified with the treatment control, in which at the $24 \mathrm{~h}$ time period it was demonstrated that the membrane integrity rates were equal to the $0 \mathrm{~h}$ time.

We also observed reduced sperm motility due to xanthan gum, which can be attributed to the increased viscosity at higher concentrations $(0.25 \%)$ of xanthan gum, potentially hindering the exchanges between the internal medium and the external cellular environment. Further, the increased viscosity due to xanthan gum may have hampered the movement of the flagellum, impeding sperm cell locomotion, even though mitochondrial functionality was largely unaffected. Previously, (Hu et al., 2009) reported that high concentrations of Gynostemma pentaphyllum polysaccharide were associated with decreased sperm motility, membrane and acrosome integrity, and post-thaw mitochondrial activity. In contrast, (Corcini et al., 2011) demonstrated that addition of $1.5 \%$ gelatin (thickening medium) in the diluent for cooled porcine semen, maintained sperm quality up to 96h, with lower seminal reflux after insemination.

The acrosome integrity measurements in the current study indicated that although high xanthan gum concentrations $(0.25 \%)$ were detrimental to acrosome integrity, lower concentrations $(0.01 \%$ and $0.12 \%)$ maintained acrosome integrity up to $24 \mathrm{~h}$. No sperm sedimentation occurred at these concentrations when compared to the control diluent, and the samples were well distributed this observation was carried out visually, in which we did not observed cellular sedimentation at the bottom of the tube where xantham gum was added. A homogeneous distribution of cells might have provided an additional layer of protection, shielding these types of structures from deleterious changes caused by cooling. On the other hand, the diluent in the liquid form led to sedimentation in this region of the storage vessel leading to increased $\mathrm{pH}$ as result of high concentration of toxic byproducts from cellular metabolism, thereby further accelerating the cellular damage. In studies carried out by Gastal et al., 2017, demonstrated that when production increased by $0.20 \%$ and $0.25 \%$, xanthan gum acted efficiently as antioxidant, since postthawing ROS production of sperm was reduced.

In certain other species of mammals, solid cooling media have demonstrated satisfactory results for semen storage, for periods longer than $24 \mathrm{~h}$ at temperatures in the range of $5-15^{\circ} \mathrm{C}$, (Yaniz et al., 2005; Salvador et al., 2006; Corcini et al., 2011). However, others (Santos et al., 2015) could not verify these results in equine semen, under the same in vitro parameters analyzed in our study, with, addition of gelatin to the standard diluents in seminal refrigeration at $5^{\circ} \mathrm{C}$ did not yield expected benefits. In humans, the higher viscosity of the seminal fluid has been associated with lower sperm motility, leading to infertility (Suarez and Dai, 1992). The hyperviscosity of the medium above physiological levels has been shown to be detrimental to the viability and stability of the sperm membrane, besides affecting the locomotion and oocyte penetration capacity (Coy et al., 2009). We agree with these interpretations considering the results of the current study using xanthan gum, when we consider in vitro aspects 
for semen quality, in diluents where milk was added and at a temperature of $5^{\circ} \mathrm{C}$, for equine species.

\section{CONCLUSION}

Based on the results obtained in this study, we conclude that xanthan gum did not present malicious effects to the sperm cell at concentrations of 0.01 and $0.12 \%$. maintaining the seminal characteristics during the cooling similar to the control, while the concentration of $0.25 \%$ reduced the seminal quality in the parameter of sperm motility. As a beneficial effect we can highlight the non-occurrence of cellular sedimentation, not requiring homogenization in the 72 hours of cooling.

\section{REFERENCES}

BEARDEN, H.J.; FUQUAY, J.W. Semen evaluation. In: _. (Eds.). Applied animal reproduction. 4.ed. New Jersey: Prentice Hall, 1997. cap.15, p.159-170.

CORCINI, C.D.; MOREIRA F.; PIGOZZO R. et al. Semen quality and reproductive performance after artificial insemination with boar sperm stored in a gelatin supplemented extender. Livest. Sci., v.138, p. 289-292, 2011.

COY, P.; GADEA, J.; RATH, D.; HUNTER, RH. Differing sperm ability to penetrate the oocyte in vivo and in vitro as revealed using colloidal preparations. Theriogenology, v.72, p.1171-1179, 2009.

EVENSON, D.P.; JOST, L.K.; MARSHALL, D. et al. Utility of the sperm chromatin structure assay as a diagnostic and prognostic tool in the human fertility clinic. Hum. Reprod., v.14, p.1039-1049, 1999.

GARCIA-OCHOA, F.; SANTOS, V.E.; CASAS, J.A.; GOMEZ, E. Xanthan gum: production, recovery, and properties. Biotechnol. Adv., v.18, p.549-579, 2000.

GARNER, D.L.; THOMAS, C.A.; JOERG, H.W. et al. Fluorometric assessments of mitochondrial function and viability in cryopreserved bovine spermatozoa. Biol. Reprod., v.57, p.1401-1406, 1997.
GASTAL, G.D.A.; SILVA, E.F.; MION, B.; VARELA JUNIOR, A.S. e al. Antioxidant effect of xanthan gum on ram sperm after freezing and thawing. CryoLetters, v.38, p.187-193, 2017.

HARRISON, R.A.; VICKERS, S.E. Use of fluorescent probes to assess membrane integrity in mammalian spermatozoa. J. Reprod. Fertil., v.88, p.343-352, 1990.

HOLT, W.V. Basic aspects of frozen storage of semen. Anim. Reprod. Sci., v.62, p.3-22, 2000.

HU, J.H.; LI, Q.W.; ZHANG, T.; JIANG, Z.L. Effect of Gynostemma Pentaphyllum polysaccharide on boar spermatozoa quality following freezing thawing. Cryobiology, v.59, p.244-249, 2009.

KAWAMOTO, A.; OHASHI, K.; KISHIKAWA, H. et al. Two-color fluorescence staining of lectin and anti-CD46 antibody to assess acrosomal status. Fertil. Steril., v.71, p.497-501, 1999.

LOPEZ-GATIUS, F.; SANCES, G.; SANCHO, M. et al. Effect of solid 294 storage at 15 degrees $\mathrm{C}$ on the subsequent motility and fertility of rabbit semen. Theriogenology, v.64, p.252-260, 2005.

NAGY, S.; SINKOVICS, G.; KOVACS, A. Viability and acrosome integrity of rabbit spermatozoa processed in a gelatin-supplemented extender. Anim. Reprod. Sci., v.70, p.283-286, 2002.

SALVADOR, I.; YANIZ, J.; VIUDES-DECASTRO, M. et al. Effect of solid storage on caprine semen conservation at 5 degrees $\mathrm{C}$. Theriogenology, v.66, p.974-981, 2006.

SAMPER, J.C.V.; KATILA, T.; NEWCOMBE, J. et al. Analysis of some factors associated with pregnancy rates of frozen semen: a multi-center study. Theriogenology, v.58, p.647-650, 2002.

SANTOS, F.C.; CORCINI, C.D.; COSTA, V.G. et al. Effect of solid medium during cooled storage on stallion sperm parameters. CryoLetters, v.36, p.313-317, 2015.

SCOTT, W.; MUNROE, D.G.; MUNROE, G. Equine clinical medicine, surgery and reproduction. In: HECHT, S.; POLLARD, R. (Eds.). Male reproduction tract. [s.1.]: Manson Publishing, 2011. p.326-373. 
SUAREZ, S.S.; DAI, X. Hyperactivation enhances mouse sperm capacity for penetrating viscoelastic media. Biol. Reprod., v.46, p.686691, 1992.

WATSON, P.F. The causes of reduced fertility with cryopreserved semen. Anim. Reprod. Sci., v.60, p.481-492, 2000.
XIONG, X.; LI, M.; XIE, J. et al. Antioxidant activity of xanthan oligosaccharides prepared by different degradation methods. Carbohydr. Polym., v.92, p.1166-1171, 2013.

YANIZ J.; MARTI, J.I.; SILVESTRE, M.A. et al. Effects of solid storage of sheep spermatozoa at 15 degrees $\mathrm{C}$ on their survival and penetrating capacity. Theriogenology, v.64, p.1844-1851, 2005. 